Никируй Л.І. ${ }^{1}$, канд. фіз.-мат. наук, Замурусва О.В. ${ }^{2}$, канд. фіз.-мат. наук, Урбан О.А. ${ }^{3}$, канд. екон. наук, Федосов С.А. ${ }^{2}$, д-р фіз.-мат. наук

${ }^{1}$ Прикарпатський національний університет імені Василя Стефаника

${ }^{2}$ Східноєвропейський національний університет імені Лесі Українки

${ }^{3}$ Луцький національний технічний університет

\title{
ВПЛИВ НАУКОВИХ ДОСЛІДЖЕНЬ НА РОЗВИТОК ВІДНОВЛЮВАЛЬНОЇ ЕНЕРГЕТИКИ
}

Сучасні дослідження в галузі відновлювальної енергетики визначають напрямки практичної реалізації різних джерел енергії. Можливість швидкого практичного застосування таких результатів має вирішальне значення для економічного зростання. У роботі аналізуються передові публікації як результати фундаментальних досліджень різних напрямків відновлювальної енергетики та визначаються ключові моменти, щзо вплинули на практичний розвиток кожної з цих галузей. Показано, як наукові дослідження в різних країнах після практичної реалізаџї впливають на їх економічний розвиток. Визначено ключових гравців світового ринку відновлювальної енергетики.

Ключові слова: відновлювальна енергетика, публікації, наукові дослідження, $h$-індекс.

Вступ. Сучасні дослідження в галузі відновлювальної енергетики визначають напрямки практичної реалізації різних джерел енергії. Можливість швидкого практичного застосування таких результатів має вирішальне значення для економічного зростання. Розкриття потенціалу відновлювальної енергетики має бути стратегічним пріоритетом для кожної держави. Це пов'язано з екологією, безпекою, економікою та політикою. Відповідно, кожна держава сьогодні намагається різними шляхами сприяти все більшій підтримці впровадження відновлювальних джерел енергії. 3 однієї сторони, це сприяння у заохоченні різних компаній впроваджувати такі технології, з іншої - вкрай необхідною є підтримка наукових досліджень у відповідних сферах. Більше того, не лише окремі держави прагнуть забезпечити свою енергетичну безпеку та незалежність, але ці процеси активно розвивають міжнародні структури, як ЄС, НАТО тощо [1].

Аналіз стану наукових досліджень може надати інформацію про фактори, які впливають на глобальне поширення відновлювальної енергетики. Результати вагомих досліджень публікують у наукових виданнях високого рівня, які індексуються міжнародними наукометричними базами Scopus та WoS, i їх зможуть цитувати інші дослідники. Веб-сайти цих баз дають можливість опрацьовувати велику кількість статистичної інформації, аналіз якої дає змогу здійснювати фахові прогнози.

Методологія досліджень. Наукові результати можна проаналізувати, якщо вони $є$ у формі публікації. Наукову літературу шукали в академічних бібліотеках, Web of Science, Scopus, рецензували англійською мовою та видавали книги, що стосуються даної тематики. Завдяки вдосконаленим інструментам наукометричних систем здійснювався пошук та відбір наукових праць. Дана методологія детально описана в роботі [2].

На першому етапі досліджень виконано повний аналіз опублікування наукових статей за ключовими словами (тегами): «Energy»» (Енергія/Енергетика), «Renewable Energy» (Відновлювальна енергія/енергетика), «Solar Energy» (Сонячна енергія/енергетика), «Wind Energy» (Вітрова енергія/енергетика), «Geothermal Energy» (Геотермальна енергія/енергетика), «Biofuel Energy» (Біопаливо та біоенергія), «Thermoelectric Energy» (Термоелектрична енергія/енергетика). Аналіз виконувався за критеріями: рік публікації, країни авторів публікації, науковий напрямок (профіль) публікації, найбільш цитовані публікації у галузі, найбільш цитовані автори у галузі. Для коректного аналізу [2] проводилося відхилення зайвих результатів двома шляхами: пошук статистичної закономірності частоти опублікованих праць за вказаними ключовими словами, але які не стосувалися саме енергетики; додавання до кожного із ключових слів серії додаткових ключових слів, які уточнювали пошук.

Також визначався певний нормалізований $\mathrm{h}$-індекс для можливості порівнювати зв'язок між кількістю публікацій за кожним тегом та якістю опублікованих матеріалів (h-індекс за тегом). Це дозволило встановити основні закономірності між розвитком зацікавленості

(С Никируй Л.І., Замурусва О.В., Урбан О.А., Федосов С.А. 
наукової спільноти до досліджень відповідних видів відновлювальної енергетики та встановити пікові етапи зростання такої зацікавленості, що можна пояснити різними факторами: створенням принципово нових підходів / технологій / матеріалів у галузі чи прийняттям відповідних законодавчих актів, що сприяли поглибленню економічної зацікавленості у розвитку конкретних напрямків.

Аналіз результатів. Аналіз публікацій щодо тегу «Energy» вимагає виваженості у дослідженні. 3 однієї сторони, за весь період можна спостерігати у базі даних Scopus близько 4 млн. публікацій. Але далеко не всі публікації стосуються тематики вироблення чи збереження енергії. Більше того, лише певна частина відповідає напрямку «Renewable / Alternative Energy» (Відновлювальної / Альтернативної енергіï) [3]. Тому, перш за все, важливо виділити групу публікацій з відновлювальної енергетики «Renewable Energy» та розділити іiі за окремими напрямками. Для зручності цього аналізу введено коефіцієнт релевантності публікацій для певного напрямку $R$ за допомогою наступного алгоритму:

1) Аналіз перших 10 сотень публікацій у Scopus, які відсортовані за цитуванням від найвищого. Відбірка публікацій, які за тематикою відповідають будь-яким процесам чи дослідженням щодо традиційної і відновлювальної енергетики. Усі інші публікації відсіюються (енергія атомних станів, енергія у питаннях, пов'язаних із астрофізикою, медициною, реабілітацією, психологією, та ін.).

2) Аналіз перших сотень публікацій у Scopus, які відсортовані за датою публікації від найновішого. Тут також проводиться вибірка кількості публікацій, як у пункті 1.

3) Встановлення частки релевантних публікацій від їх загальної кількості $R=N_{r e l} / N$, де $N_{r e l}$ - кількість відображених у результаті пошуку публікацій (у даному випадку традиційної та відновлювальної енергетики), а $N$ - загальна кількість публікацій, що відображаються за назвою обраного тегу. Аналогічна процедура здійснюється за іншими тегами, які відповідають ключовим напрямкам досліджень відновлювальної енергетики. Отримані результати відображено у таблиці 1.

Коефіціснт релевантності публікацій за напрямками

\begin{tabular}{llcc}
\hline № & \multicolumn{1}{c}{ Напрямки } & $\boldsymbol{R}_{\mathbf{1}}$ (за цитуванням) & $\boldsymbol{R}_{\mathbf{2}}$ (за останні роки) \\
\hline $\mathbf{1 .}$ & Energy & 0,47 & 0,68 \\
$\mathbf{2 .}$ & Wind energy & 0,61 & 0,94 \\
$\mathbf{3 .}$ & Solar energy & 0,84 & 0,91 \\
$\mathbf{4 .}$ & Biofuel energy & 0,99 & 0,98 \\
$\mathbf{5 .}$ & Geothermal energy & 0,88 & 0,97 \\
$\mathbf{6 .}$ & Thermoelectric energy & 0,92 & 0,88 \\
\hline
\end{tabular}

Коефіцієнт $R=1$ можливий у дуже ідеалістичному випадку, коли назва ключового тега повністю відповідає конкретному та єдиному тегу. Такий випадок $є$ ідеальним і не може бути реалізований практично, але за певними напрямками значення може бути дуже близьким до 1.

Як і очікувалося (табл. 1), найбільше відхилення від 1 спостерігається для тегу «Energy». За результатами аналізу найбільш цитованих та найбільш нових публікацій значенням $R$ виявилися різними. Це можна пояснити наступними міркуваннями. Найбільш цитованими роботами $є$ статті, які описують принципово нові підходи чи моделі, $є$ абсолютно новими або започатковують новий напрям досліджень. Для випадку з тегом «Energy», як виявилося [2], найбільш цитованими роботами стали публікації, які описують основні принципи ab initio розрахунків чи інших теоретичних розрахунків електронних станів. Це зрозуміло, оскільки наведені в них принципи, стали основою математичного апарату сучасної теоретичної фізики. Лише десята за цитованістю робота [4] відповідає досліджуваному напрямку та містить 21141 цитування. Тому коефіцієнт релевантності 0,47 є реальним.

Для коефіцієнту релевантності для публікацій, які аналізувались як найновіші, то $R$ тут збільшився до 0,68. Це свідчить про загальне зростання наукового інтересу до енергетичних проблем. Причому, саме відновлювальних джерел енергії, оскільки відновлювальна енергетика 3 кожним роком все більше заміщує традиційну, яка базується на спалюванні ресурсів із виділенням шкідливих для навколишнього середовища речовин, затопленні територій чи використанні атомних станцій. Найшвидше ж впровадження нових ідей сприятиме загальному покращенню екологічної та енергетичної ситуації у світі.

(С Никируй Л.І., Замурусва О.В., Урбан О.А., Федосов С.А. 
Щодо інших тегів, там було знайдено кілька важливих закономірностей. Дуже сильно відрізняються коефіцієнти $R$ для тегу «Wind Energy» (Вітрова енергія). Досить низький коефіцієнт 0,61 для співпадання публікацій із високою кількістю цитувань пояснюється наявністю у переліку статей за тематикою астрофізики, які описують процеси у великих космічних об'єктах, рух галактик, тощо. Крім того, дуже велика кількість публікацій стосуються не прямо генерування електроенергії від вітру, а фізиці та механіці окремих частин вітрогенераторів, які використовуються і цитуються з іншими напрямками (наприклад, «Solar Energy», (Сонячна енергія)) та стосуються матеріалів для акумуляторів чи конструкцій певних двигунів [5]. Проте за останні роки питання перетворення енергії вітру в електричну стало найбільш актуальним за даним пошуковим запитом. Слід відзначити i конструктивні особливості нових моделей вітрогенераторів та їх систем, екологічні проблеми їх роботи, а також розрахунки економічної ефективності. Важливим фактором є те, що вітрова енергія один із найпоширеніших видів відновлювальної енергетики, яка вже активно виробляється та щорічно якнайбільше поширюється в різних країнах. Так, за 2015 році у світі було вироблено 432680 МВт вітрової електроенергії, а у 2016 році - 486749 МВт [6]. Знижується також і вартість такої електроенергії до рівня 0,04 дол.США/кВт·год [7]. Також існує значно більша кількість журналів, які присвячені питанням генерування вітрової електроенергії у порівнянні із астрофізичною тематикою, яка хоча і $є$ більш цитованою, але нею займається значно менша кількість дослідників.

Схожа картина спостерігається при дослідженні сонячної енергетики. На відміну від інших досліджень, тут поєднано в єдиний тег «Solar Photoelectric / PV» (Сонячна фотоелектрика / ФВ) та «Solar Heat Energy» (Сонячна теплова енергія). Фізика цих процесів принципово різна, однак, для них існує спільне джерело безкоштовної енергії - Сонце. Різниця у цьому випадку між $R_{1}$ і $R_{2}$ менша, але $\epsilon$ стабільне відхилення їх значень від 1. Отже перетворення сонячної енергії в електричну чи теплову, які були б корисні для людини, значно раніше почали цікавити дослідників і тепер вони стабілізувалися на певних пропорційних до кількості публікацій значеннях $(0,84$ та 0,91$)$ щодо інших публікацій, які зустрічаються за цими тегами. До інших областей досліджень тут однозначно відносять астрофізичні (процеси на Сонці), аерокосмічні та «чисті» географічно-екологічні дослідження. Хоча значення (близькі до 0,9) свідчать про високий імпакт досліджень щодо сонячної енергетики, який підтримується як державними механізмами у різних країнах, так і бізнесом, для яких впровадження інновацій є одночасно $\mathrm{i}$ комерційним і суспільним успіхом.

Інші два теги «Biofuel Energy» (Енергія біопалива) (включаючи агробіопаливо, біомасу тощо) та «Geothermal Energy» (Геотермальна енергія) відносяться до тих видів відновлювальної енергетики, які насьогодні успішно впроваджуються на практиці, мають відповідні наукові обгрунтування та дослідження, але у кількості виробленої енергії суттєво поступаються «Solar Energy» та «Wind Energy»[8]. Однак інформація про них є невід'ємною та важливою складовою частиною усіх сучасних оглядів та проектів $[1,6,7]$. Щодо «Biofuel Energy», то спостерігаються дуже близькі значення між $R_{1}$ і $R_{2}$ (0,99 і 0,98 відповідно). Це свідчить про чітку тематичну спрямованість таких публікацій. Щодо «Geothermal Energy», то релевантність публікацій відповідно до тематики відновлювальної енергетики в останні роки досить висока і становить 0,97. Дещо нижче значення серед числа найбільш цитованих публікацій за цим напрямком можна легко пояснити дослідженнями у геології чи науки про Землю.

В останні роки дуже потужною стала термоелектрична індустрія - «Thermoelectric Energy» (Термоелектрична енергія). Зокрема, на Міжнародній конференції з термоелектрики ICT2017 у Пасадені, США взяли участь 557 організацій (університети, дослідницькі центри і компанії з цілого світу). Лише для цього напрямку спостерігається значення $R_{1}$ вище $R_{2}$. Тобто, найбільш цитовані публікації становлять переважну частину відносно інших можливих матеріалів. Наприклад, коли досліджуються матеріали чи ефекти, які могли б використовуватися для виробництва термоелектричної енергії, але самі вони призначені для інших цілей. А практична можливість прямого перетворення тепла в електрику без застосування складних рухомих механізмів та без спеціального спалювання сировини сьогодні $\epsilon$ важливим економічним та екологічним фактором. Причому, щорічно зростає і кількість, i якість публікацій цього напрямку.

Іншим цікавим прикладом є те, що до 1970-их років кількість публікацій за окремими напрямками відновлювальної енергетики складала одиниці чи рідко - десятки публікацій у рік.

(С Никируй Л.І., Замурусва О.В., Урбан О.А., Федосов С.А. 
3 початку 1970-их років ситуація змінилася і спостерігається спочатку плавне зростання, а 3 2001-2008 pp. - стрімкий нелінійний ріст кількості публікацій. Тобто, з того часу прийшло усвідомлення для світової спільноти тематики вичерпності природних ресурсів та необхідності переорієнтації на зменшення викидів у навколишнє середовище.

Відповідно до цього, важливо проаналізувати якість публікацій, яка визначається у науковій спільноті кількістю їх цитувань. На рис. 1 наведено співвідношення між h-індексами публікацій у напрямку відновлювальної енергетики i енергетики (рис. 1a) та кількості публікацій лише за окремими напрямками відновлювальної енергетики (рис. 1б). Загальна кількість публікацій за тегом «Energy» не береться до уваги, оскільки ця кількість включає у тому числі й кількість публікацій за всіма видами відновлювальної енергетики і $є$ значно вищою. Це ускладнює адекватне сприйняття графічного матеріалу.

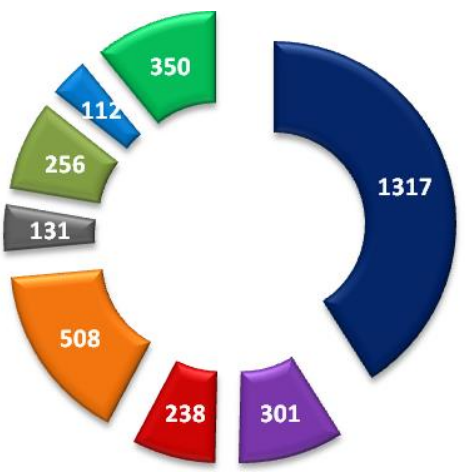

a)

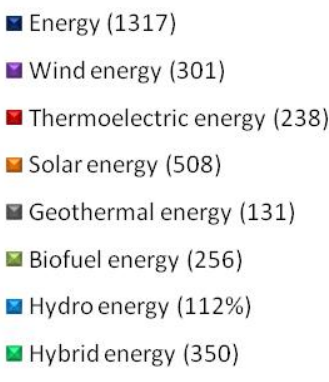

四 Hybrid energy (350)

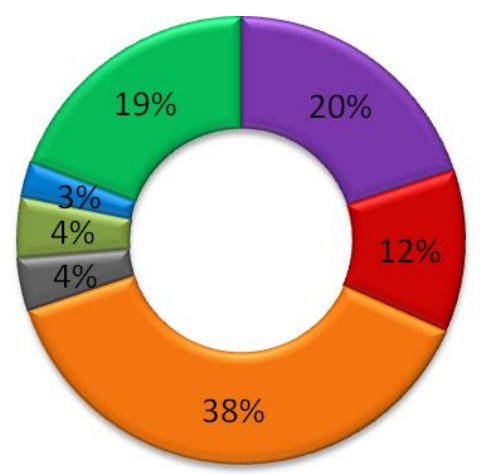

б)

Рис. 1. Сумарний h-індекс (а) та загальна кількість публікацій у відсотках (б), пов'язаних із енергією в цілому та окремими видами відновлювальної енергетики.

Для цього аналізу було розглянуто ще один додатковий тег «Hybrid Energy» (Гібридна енергія), оскільки дуже часто сьогодні намагаються покращити існуючі системи відновлювальної енергетики через поєднання різних механізмів в єдиному комплексі. Це дає змогу при затраті менших коштів отримати систему із значно вищою ефективністю у порівнянні 3 ефективністю кожної окремої системи. Для двох окремих систем повна ефективність може бути вищою, але їх вартість буде набагато вищою за гібридну систему, що робить використання двох таких систем окремо економічно невигідним.

Якщо розглянути окремі напрямки, то чітко видно, що як за цитуванням, так і за кількістю публікацій найвище значення має тег «Solar Energy»: h=508 (або 38 \%) загальної кількості публікацій за тематикою відновлювальної енергетики. Дуже близькі показники за обома параметрами мають теги «Wind Energy» ( $\mathrm{h}=301$, або 20 \%) i «Hybrid Energy» ( $\mathrm{h}=350$, або $19 \%$ ). Такі значення за цими тегами зрозумілі та передбачувані. Адже саме сонячна енергія i вітрова енергія сьогодні є вирішальними з економічної точки зору і першими почали масово впроваджуватися [7]. Основні публікації стосуються високотехнологічної сфери щодо принципово нових ідей, які стимулюють новий етап розвитку галузі. Так, у [4] обгрунтовано можливість розробки дешевих та комерційно вигідних фотоелементів товщиною 10 мкм на основі оптично прозорих плівок із наночастинок діоксину титану. Ці наночастинки збирають достатньо високий відсоток потоку сонячного випромінювання (46\%) i демонструють виняткові показники перетворення енергії фотона в електричну енергію із загальною ефективністю $(7,1-7,9) \%$. Схожим матеріалам присвячені й інші роботи, де пропонується певна хімічна модифікація цих фотоелементів на основі $\mathrm{TiO}_{2}$ через легування елементами нітрогену, розробка поверхнево активного наноструктурного діоксину титану, тощо. Тобто, чітко видно, що найбільш цитованими $є$ наукові дослідження у сфері фотоелектричного матеріалознавства. Для «Wind Energy» ситуація інша. Більш вагомими (цитованими) є матеріали, які стосуються систем перетворення енергії у цілому, у т.ч., й вітрової, а також інженерно-технічних та конструкторських рішень вітрових станцій. Також $є$ частина публікацій, які відповідають тематиці матеріалознавства $(5,4 \%)$, але далеко не всі вони стосуються суто матеріалів для турбін, лопатей або корпусів. Значна кількість публікацій присвячена матеріалам акумуляторних батарей, які можуть використовуватися і для інших видів відновлювальної енергетики [5].

(C) Никируй Л.І., Замурусва О.В., Урбан О.А., Федосов С.А. 
Порівнюючи відсотковий вміст внеску саме статей із галузі матеріалознавства у кожен із видів відновлювальної енергетики, як розділу, який для цих напрямків найбільше відповідає фундаментальній природничій науці, то можна побачити наступний розподіл (включаючи Chemical Engineering (хімічну інженерію)): Solar Energy - 40,4\%, Wind Energy - 5,4\%, Geothermal Energy - 11,3 \%, Biofuel Energy - 35,9\%, Thermoelectric Energy - 50,4 \%, Energy 42,6\%. Тобто, до технологічних сфер, які мають вагому наукову складову, найбільше відноситься Thermoelectric Energy, Solar Energy i Biofuel Energy. Причому, значний відрив Thermoelectric Energy від Solar Energy можна пояснити саме перспективою термоелектрики. Але термоелектричні перетворювачі не завжди можуть бути самостійними джерелами електричної енергії, часто вони є додатковими чи допоміжними для покращення екологічної ситуації. Суто лише термоелектричне перетворення енергії використовується на практиці значно рідше, ніж фотоелектричне. Відповідно, кількість опублікованих робіт за тегом «Thermoelectric Energy» складає $12 \%$ (рис. 1б).

Значно менша кількість робіт стосується Biofuel Energy (4\%), Geothermal Energy (4 \%), Hydro Energy (3\%). Але існує досить потужна практична реалізація. Тобто, на ринку $є$ велика кількість гравців, які комерційно впроваджують ці напрямки, користуючись великими підтримками на рівні держав та використовуючи їх природний та виробничий потенціали. Тому й імпакти цієї невеликої у відсотках кількості публікацій достатньо високі (рис. 1а).

Враховуючи релевантність цитувань за напрямками (табл. 1) та перемноживши ці значення на величини h-індексу та кількості публікацій, отримаємо певні нормалізовані значення цих параметрів (рис. 2).

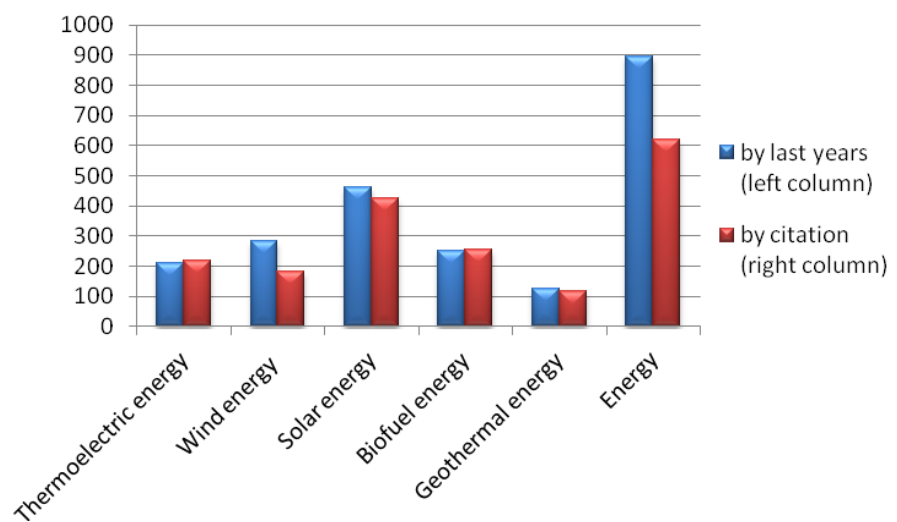

a)

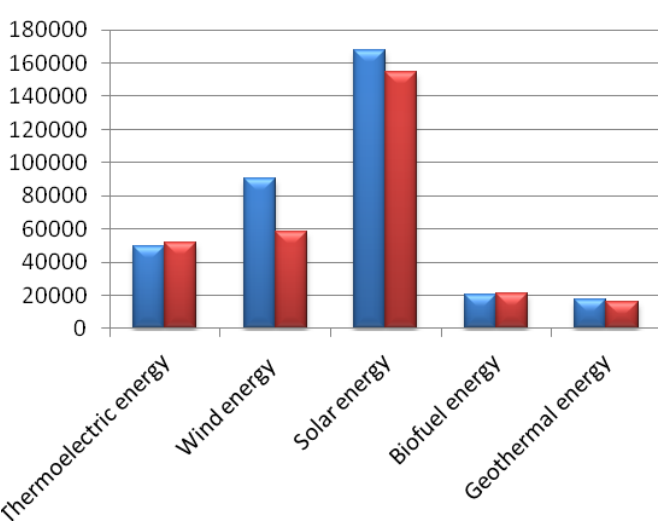

б)

Рис. 2. Нормалізовані значення h-індексу (а) та кількості публікацій (б) за науковими напрямками

Як видно, дані на рис. 2 повністю відповідають наведеним вище висновкам i припущенням. Цікаво відзначити той факт, що нормалізоване значення кількості публікацій вказує на більшу кількість статей, які вийшли за останні роки, ніж статей, які мають високі посилання, спостерігається лише для тегу «Thermoelectric Energy» (рис. 2б). Це свідчить про достатньо нові публікації у цій сфері, а також про посилення зацікавленості до цієї тематики в останні роки.

Певну статистику щодо публікацій наведено у таблиці 2. Однозначними країнами лідерами щодо публікацій у сфері енергетики, у т.ч., відновлювальної енергетики, є США та Китай. $€$ країни, які мають національні пріоритети у сфері енергетики. Вони займають різні порядкові місця у цій таблиці, залежно від певного типу відновлювальної енергетики. Це часто пов'язано із географічним розташуванням країни, або із власною державною політикою. Як США, так і Китай географічно розташовані у різних географічних поясах, а також кожна із цих держав має потужні дослідницькі центри. Тому їх 1-a і 2-a позиції є очевидними. Німеччина, Великобританія, Індія, Японія, Канада, Італія, Франція - це країни, які обрали енергетичну безпеку у якості свого національного інтересу.

Наприклад, Індія задекларувала перехід на $100 \%$ відновлювальну енергетику до 2022 року. Основою відновлювальної енергетики в Індії буде сонячна енергетика. Тому саме у сонячній енергетиці Індія займає 3 місце у світі за кількістю публікацій. Ця сама тенденція $є$ і у виробництві сонячної електроенергії. Лідируючі позиції в розвитку сонячної енергетики займають Китай (52 ГВт), США (12,5 ГВт) та Індія (9 ГВт) [7].

(С Никируй Л.І., Замурусва О.В., Урбан О.А., Федосов С.А. 
Ситуація щодо науково-дослідних центрів, які займають провідні позиції за кількістю публікацій, дещо відмінна від рейтингу за державою. Існують центри, які, як виявилося, $\epsilon$ однозначними лідерами в енергетичних дослідженнях. Причому, це одночасно може бути i розробка політики щодо екологічних норм джерел енергії, і розробка принципово нових матеріалів та пристроїв. Тобто, існують організації, які здобули незаперечну позитивну репутацію (табл. 2, рядок 2): CNRS, University of Tokyo, UC Berkeley, MIT, NASA Goddart Space Flight Center, National Renewable Energy Laboratory, California Institute of Technology, Tsinghua University, Technical University of Denmark та ін.

Таблиця 2

Статистика кількості публікацій за країнами відповідно до різних ключових тегів [2]

\begin{tabular}{|c|c|c|c|c|c|c|}
\hline № & Energy & $\begin{array}{c}\text { Solar } \\
\text { Energy }\end{array}$ & $\begin{array}{c}\text { Wind } \\
\text { Energy }\end{array}$ & $\begin{array}{l}\text { Thermoelect } \\
\text { ric Energy }\end{array}$ & $\begin{array}{l}\text { Biofuel } \\
\text { Energy }\end{array}$ & $\begin{array}{c}\text { Renewable } \\
\text { Energy }\end{array}$ \\
\hline 1. & $\begin{array}{l}\text { 1. USA } \\
\text { 2. China } \\
\text { 3. Germany } \\
\text { 4. Japan } \\
\text { 5. UK } \\
\text { 6. France } \\
\text { 7. India } \\
\text { 8. Italy }\end{array}$ & $\begin{array}{l}\text { 1. USA } \\
\text { 2. China } \\
\text { 3. India } \\
\text { 4. Germany } \\
\text { 5. Japan } \\
\text { 6. UK } \\
\text { 7. Italy } \\
\text { 8. France }\end{array}$ & $\begin{array}{l}\text { 1. USA } \\
\text { 2. China } \\
\text { 3. UK } \\
\text { 4. Germany } \\
\text { 5. India } \\
\text { 6. Japan } \\
\text { 7. Canada } \\
\text { 8. France }\end{array}$ & $\begin{array}{l}\text { 1. USA } \\
\text { 2. China } \\
\text { 3. Japan } \\
\text { 4. India } \\
\text { 5. Germany } \\
\text { 6. UK } \\
\text { 7. South } \\
\text { Korea } \\
\text { 8. France }\end{array}$ & $\begin{array}{l}\text { 1. USA } \\
\text { 2. China } \\
\text { 3. India } \\
\text { 4. UK } \\
\text { 5. Germany } \\
\text { 6. Brazil } \\
\text { 7. Italy } \\
\text { 8. Canada }\end{array}$ & $\begin{array}{l}\text { 1. USA } \\
\text { 2. China } \\
\text { 3. UK } \\
\text { 4. Germany } \\
\text { 5. India } \\
\text { 6. Italy } \\
\text { 7. Spain } \\
\text { 8. Canada }\end{array}$ \\
\hline 2. & $\begin{array}{l}\text { 1. CNRS } \\
\text { 2. Univ. } \\
\text { Tokyo } \\
\text { 3. UC } \\
\text { Berkeley } \\
\text { 4. MIT } \\
\text { 5. Inst. } \\
\text { Nazionale } \\
\text { de Fisica } \\
\text { Nucleare }\end{array}$ & $\begin{array}{l}\text { 1. NASA } \\
\text { Goddart } \\
\text { Space } \\
\text { Flight } \\
\text { Center } \\
\text { 2. Nat. } \\
\text { Renewabl } \\
\text { e Energy } \\
\text { Lab. } \\
\text { 3. CNRS } \\
\text { 4.UC } \\
\text { Berkeley } \\
\text { 5. Cal. Tech. }\end{array}$ & $\begin{array}{l}\text { 1. NASA } \\
\text { Goddart } \\
\text { Space } \\
\text { Flight } \\
\text { Center } \\
\text { 2. Danmarks } \\
\text { Tek. Univ. } \\
\text { 3. CNRS } \\
\text { 4. UC } \\
\text { Berkeley } \\
\text { 5. Nat. } \\
\text { Renewabl } \\
\text { e Energy } \\
\text { Lab. }\end{array}$ & $\begin{array}{l}\text { 1. MIT } \\
\text { 2. Cal. Tech. } \\
\text { 3. Tsinghua } \\
\text { Univ. } \\
\text { 4. CNRS } \\
\text { 5. Wuhan } \\
\text { Univ. }\end{array}$ & $\begin{array}{l}\text { 1. UC } \\
\text { Berkeley } \\
\text { 2. USDA } \\
\text { Agr. Res. } \\
\text { Center } \\
\text { 3. US Deprt. } \\
\text { Agr. } \\
\text { 4. Univ. Sao } \\
\text { Paolo } \\
\text { 5. Oak Ridge } \\
\text { Nat. Lab. }\end{array}$ & $\begin{array}{l}\text { 1. Nat. } \\
\text { Renewabl } \\
\text { e Energy } \\
\text { Lab. } \\
\text { 2. Tsinghua } \\
\text { Univ. } \\
\text { 3. Aalborg } \\
\text { Univ. } \\
\text { 4. Danmarks } \\
\text { Tek. Univ. } \\
\text { 5. North } \\
\text { China } \\
\text { Elect. } \\
\text { Pow. } \\
\text { Univ. }\end{array}$ \\
\hline 3. & $\begin{array}{l}\text { 1. European } \\
\text { Org. for } \\
\text { Nuclear } \\
\text { Res., } \\
\text { Geneve, } \\
\text { Switzerlan } \\
\text { d } \\
\text { 2. Tata Inst. } \\
\text { of Fund. } \\
\text { Res., } \\
\text { Mumbai, } \\
\text { India } \\
\text { 3. Univ. } \\
\text { Bergen, } \\
\text { Bergen, } \\
\text { Norway }\end{array}$ & $\begin{array}{l}\text { 1. Max } \\
\text { Planck } \\
\text { Institute } \\
\text { for Solid } \\
\text { State } \\
\text { Research, } \\
\text { Stuttgart, } \\
\text { Germany } \\
\text { 2. ETH } \\
\text { Zurich, } \\
\text { Zurich, } \\
\text { Switzerlan } \\
\text { d } \\
\text { 3. Univ. of } \\
\text { Ontario } \\
\text { Oshawa, } \\
\text { Canada }\end{array}$ & $\begin{array}{l}\text { 1. Univ. of } \\
\text { the } \\
\text { Ryukyus, } \\
\text { Nakagami } \\
\text { District, } \\
\text { Japan } \\
\text { 2. Princeton } \\
\text { Univ., } \\
\text { Princeton, } \\
\text { USA } \\
\text { 3. Nagoya } \\
\text { Univ., } \\
\text { Nagoya, } \\
\text { Japan }\end{array}$ & $\begin{array}{l}\text { 1. Northwest } \\
\text { ern Univ., } \\
\text { Evanston, } \\
\text { USA } \\
\text { 2. Northwest } \\
\text { ern Univ., } \\
\text { Evanston, } \\
\text { USA } \\
\text { 3. Purdue } \\
\text { Univ., } \\
\text { Lafayette, } \\
\text { USA }\end{array}$ & $\begin{array}{l}\text { 1. Univ. of } \\
\text { Utah, Salt } \\
\text { Lake City, } \\
\text { USA } \\
\text { 2. Univ. } \\
\text { College } \\
\text { Cork, } \\
\text { Cork, } \\
\text { Ireland } \\
\text { 3. Univ. of } \\
\text { Groningen } \\
\text { Groningen } \\
\text {, } \\
\text { Netherlan } \\
\text { ds }\end{array}$ & $\begin{array}{l}\text { 1. Univ. of } \\
\text { the } \\
\text { Ryukyus, } \\
\text { Nakagami } \\
\text { District, } \\
\text { Japan } \\
\text { 2. Univ. of } \\
\text { Ontario } \\
\text { Oshawa, } \\
\text { Canada } \\
\text { 3. Aalborg } \\
\text { Univ., } \\
\text { Aalborg, } \\
\text { Denmark }\end{array}$ \\
\hline
\end{tabular}


Але ще цікавішим $є$ третій рядок табл. 2, у якому наведено центри, які $є$ найбільш цитованими у своїй галузі. Відбір проводився за найцитованішими дослідниками із цих центрів (наведено афіліацію найбільш визнаних вчених). У термоелектриці перші дві позиції займає один і той же університет: Northwestern University (США). За іншими напрямками наведені заклади не входять у перелік організацій із рядка 2. Тобто, загальна кількість публікацій авторів із закладів, що вказані у рядку $3 \epsilon$ меншою, але саме вони $є$ флагманами, тобто тими, хто $\epsilon$ «засновником тенденцій». I виявляється, що ці «засновники тенденцій» представляють організації не лише із США, Канади, Японії, Німеччини, Індії, але й із Швейцарії, Норвегії, Данії, Нідерландів, які не входять у перелік держав, наведених у рядку 1 табл. 2. Тобто, якщо певна держава не входить до переліку тих країн, які видають найбільшу кількість публікацій, тим не менш, дослідники 3 них можуть претендувати на найвищі позиції у рангу світових вчених. I друге, дуже цікавим виявилося певне «зміщення» у тих організаціях, де працюють найбільш цитовані дослідники у скандинавських держав. А з іншої сторони, саме держави, наведені у рядку 3 табл. 2, мають найбільшу кількість нобелівських лауреатів. Це ще раз підтверджує, що статистика відкритих даних міжнародних науко-метричних баз дає вірогідний результат і сприяє наданню достовірних висновків.

Також, дуже важливі висновки отримуються із побудови графіків зростання кількості публікацій $з$ роками. Зокрема, математичним інструментами можна здійснити обробку побудованих графіків та усереднити їх асимптоматичною кривою. Як виявилося, найбільш вдалими кривими, які плавно описують статистичні дані по кількості публікацій є поліноми 4ого, 5-ого і 6-ого порядків (рис. 3). Самі поліноми для досліджуваних тегів наведено в таблиці 3.

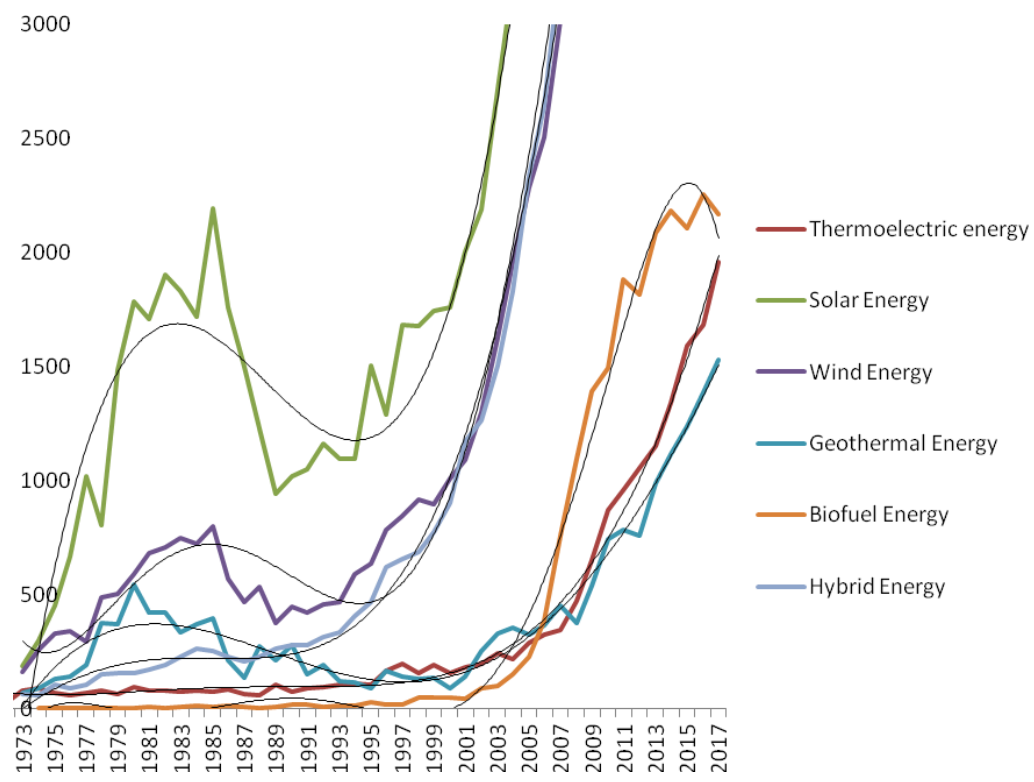

Рис. 3. Залежності кількості публікацій з роками та їх усереднення асимптоматичною кривою за науковими напрямками

Таблиця 3

Поліноми, які описують ріст кількості публікацій за роками у всьому світі

\begin{tabular}{lll}
\hline № & \multicolumn{1}{c}{ Напрямки } & \multicolumn{1}{c}{ Поліноми } \\
\hline 1. & Energy & $y=-0,0966 x^{4}+5,5003 x^{3}+131,31 x^{2}-13592 x+257094$ \\
2. & Wind energy & $y=0,0009 x^{5}-0,1054 x^{4}+4,4025 x^{3}-61,431 x^{2}-242,42 x+8973,5$ \\
3. & Solar energy & $y=-0,0003 x^{4}-0,6833 x^{3}+62,356 x^{2}-1794,5 x+17876$ \\
4. & Biofuel energy & $y=-3 \times 10^{-5} x^{6}+0,0052 x^{5}-0,3152 x^{4}+9,066 x^{3}-121,05 x^{2}+$ \\
& & $+499,36 x+1674,3$ \\
5. & Geothermal energy & $y=-0,0017 x^{4}+0,068 x^{3}+2,9287 x^{2}-148,58 x+1650,5$ \\
6. & Thermoelectric & $y=0,0021 x^{4}-0,2742 x^{3}+13,193 x^{2}-277,27 x+2251,6$ \\
& energy & $y=0,0045 x^{4}-0,778 x^{3}+45,25 x^{2}-1228,4 x+11877$ \\
\hline
\end{tabular}

(С Никируй Л.І., Замурусва О.В., Урбан О.А., Федосов С.А. 
Очевидним є існування певних причин, які б могли пояснити різкі зміни у зростанні кількості публікацій. Так, різке збільшення кількості публікацій у 1975 році за тегом «Solar Energy» було пояснено наступним. У 1973 році відбулися кілька потрясінь світового масштабу. Так, через появу у 1960-их роках великих нафтових танкерів, Японія змогла налагодити поставки з Середнього Сходу. Тоді нафтове ембарго 1973-го і наступне за ним стрімке зростання цін на нафтові енергоресурси послужили поштовхом до відновлення національного «сонячного» ринку [9]. 3 іншої сторони, успіх військової операції Ізраїлю на початку 1970-их привів до масштабного нафтовому бойкоту в 1973 році. Це були деякі причини, які змусили світ побачити нестабільність існуючого енергетичного стану та шукати альтернативу. Таким чином, розпочався бум сонячної енергетики. Спочатку це було дослідження щодо використання концентрованої теплової сонячної енергії (сонячні колектори, водонагрівачі та ін.), а далі - фотоелектричне перетворення сонячної енергії. Пік спостерігається у 19811982 роках. Перед цим, у 1978 році у США вперше було введено «зелений тариф».

Наступний ріст спостерігається з 2000-их років, коли різні держави, особливо у теплій кліматичній зоні почали зобов'язувати жителів ставити на своїх будинках теплові колектори. Пошук більш дешевих колекторів, а також сонячних фотоелектричних станцій та гібридних систем став новою причиною збільшення кількості публікацій у цьому напрямку. У 1997 році було підписано Амстердамський договір, у якому був закладений принцип сталого розвитку для ЄС. Зокрема, у цьому договорі йшла мова про покращення виробництва поновлювальних джерел енергії. Це вже була не окрема ініціатива, наприклад, як у Німеччини в 1991 році, а спільна ініціатива багатьох держав, яка спричинила новий крок у розвитку відновлювальної енергетики.

Вітрова енергетика (Wind Energy) теж розвивалася за законами, схожими до тих, які описують сонячну (Solar Energy). Зміщення на 1-2 роки піку росту «Wind Energy» (рис. 3) спричинено іншими передумовами для розвитку вітрової енергетики. Малі вітрові станції, які завжди існували, наприклад, у Данії, не могли забезпечити потрібного росту генерування такої енергії у достатній кількості. Тому уряд США підтримував розробку у NASA надпотужних вітрових турбін з 1971 року. Уже в 1981 році було створено першу турбіну на 7,5 МВт [10]. Тут так само, після першого піку, зумовленого дослідницькими чинниками, друге потужне зростання кількості публікацій зумовлене введенням зеленого тарифу у різних державах, як це спостерігається у Solar Energy.

Ріст кількості публікацій за тематикою «Thermoelectric Energy» спричинений двома чинниками: (I) створенням нового типу термоелектричних матеріалів, зокрема, композитних матеріалів із нановключеннями [11] та (II) розвиток економічної конкуренції між промисловими компаніями, зокрема, створенням умов певними державами для здешевлення кінцевих пристроїв. Таким чином, різко почали розвиватися технології здешевлення синтезу матеріалів та компактування модулів. Це було причиною збільшення уваги до термоелектрики науковців, а отже й різкого збільшення кількості публікацій. Аналогічно до термоелектрики спостерігається зростання «Geothermal Energy», «Biofuel Energy» без наявності додаткових піків.

Висновки. Для адекватного передбачення розвитку відновлювальної енергетики, необхідно одночасно враховувати ряд факторів і це не лише ціна або наявність самих систем. Також необхідно враховувати динаміку отримання результатів, їх якість та можливість поширення. Саме тому на перший план виходить багатофакторний аналіз наукових публікацій, як основний метод поширення результатів наукових досліджень. Щодо різних факторів, що випливають із статистики наукових публікацій, головним $є$ показник сприйняття результатів досліджень науковою спільнотою, або, як його часто називають, індекс цитат, а також кількість публікацій за рік та галузями.

Кількість наукових публікацій на тему відновлювальної енергетики безпосередньо визначається економічним станом країни, в якій проводяться дослідження. Якість наукових публікацій або їх цитування також залежить від рівня фінансування досліджень. Публікації дослідників з економічно менш потужних держав також можуть мати конкурентоспроможні наукові результати. Однак через відсутність «відкритого доступу», який часто потребує додаткового фінансування, такі видання менш відомі вченим 3 інших країн, а тому їх «видимість» $\epsilon$ нижчою як для наукової спільноти, так i для виробничих компаній як потенційних майбутніх донорів. 
Методологія, запропонована в цій роботі, може бути основою для майбутніх досліджень конкретних напрямків відновлювальної енергетики. Аналіз якості опублікованих результатів досліджень - це єдине джерело інформації для складання професійних бізнес-планів для великих компаній, які хочуть вийти на нові ринки або стартапи під час впровадження нових ідей у сфері відновлювальної енергетики. Для того, щоб публікації мали позитивний вплив на економічний розвиток, вони повинні бути максимально доступними для наукової спільноти. Одним з найбільш ефективних варіантів може бути спільне міжнародне дослідження.

\section{Інформаційні джерела}

1. Energy DG, European Commission. EU, Energy in Figures, Statistical Pocketbook 2017. Brussels: Publications Office of the European Union, 2017. 265 p. DOI: 10.2833/80717

2. Wisz G, Nykyruy L, Yakubiv V, Hryhoruk I, Yavorskyi R. Impact of Advanced Research on Development of Renewable Energy Policy: Case of Ukraine. Int. J. Renewable Energy Res. 2018. Vol. 8, № 4. P. 2367-2384.

3. Dresselhaus M., Thomas I. Alternative Energy Technologies. Nature. 2001. Vol. 414. P. 332-337. DOI: $10.1038 / 35104599$

4. O'regan B., Grätzel M. A Low-cost, High-efficiency Solar Cell Based on Dye-sensitized Colloidal $\mathrm{TiO}_{2}$ Films. Nature. 1991. Vol. 353. P. 737-740. DOI: 10.1038/353737a0

5. Kang B., Ceder G. Battery Materials for Ultrafast Charging and Discharging, Nature. 2009. Vol. 458. P. 190-193. DOI: $10.1038 /$ nature07853

6. Global Wind Statistics 2016 [accessed 10 Feb. 2017]. Brussels : Global Wind Energy Council, 2017.

7. Renewable Power Generation Costs in 2017. Abu Dhabi : International Renewable Energy Agency, 2018. $160 \mathrm{p}$.

8. Ehrlich R., Geller H.A. Renewable Energy, 2nd Ed.: A First Course. CRC Press, 2017. 490 p.

9. Bainbridge D. A. The Integral Passive Solar Water Heater Book. The Passive Solar Institute, $1981.99 \mathrm{p}$.

10. web-source: http://www.windsofchange.dk/WOC-usastat.php

11. Snyder G.J., Toberer E.S. Complex Thermoelectric Materials. Nat. Mat. 2008. Vol. 7. P. 105-114. DOI: $10.1038 / \mathrm{nmat} 2090$

Никируй Л.И. ${ }^{1}$, канд. физ.-мат. наук, Замуруева О.В. ${ }^{2}$, канд. физ.-мат. наук, Урбан О.А. ${ }^{3}$, канд. экон. наук, Федосов С.А. ${ }^{2}$, д-р физ.-мат. наук

${ }^{1}$ Прикарпатский национальный университет имени Василия Стефаника

${ }^{2}$ Восточноевропейский национальный университет имени Леси Украинки

${ }^{3}$ Луцкий национальный технический университет

\section{ВЛИЯНИЕ НАУЧНЫХ ИССЛЕДОВАНИЙ НА РАЗВИТИЕ ВОЗОБНОВЛЯЕМОЙ ЭНЕРГЕТИКИ}

Современные исследования в области возобновляемой энергетики определяют направления практической реализации различных источников энергии. Возможность быстрого практического применения таких результатов имеет решающее значение для экономического роста. В работе анализируются передовые публикаиии как результаты фундаментальных исследований для различных направлений возобновляемой энергетики и определяются ключевые моменты, которые повлияли на практическое развитие каждой из этих областей. Показано, как научные исследования в разных странах после практической реализации влияют на их экономическое развитие. Определены ключевые игроки возобновляемой энергетики на мировом рынке.

Ключевые слова: возобновляемая энергетика, публикации, научные исследования, $h$ индекс.

(С) Никируй Л.І., Замуруєва О.В., Урбан О.А., Федосов С.А. 
Nykyruy L.I. ${ }^{1}$, Cand. Sc. (Phys. \& Math.), Zamurujeva O.V. ${ }^{2}$, Cand. Sc. (Phys. \& Math.), Urban O.A. ${ }^{3}$, Cand. Sc. (Econ.), Fedosov S.A. ${ }^{2}$, Dr. Phys. \& Math. Sc.

${ }^{1}$ Vasyl Stefanyk Precarpathian National University

${ }^{2}$ Lesya Ukrainka Eastern European National University

${ }^{3}$ Lutsk National Technical University

\section{THE IMPACT OF SCIENTIFIC RESEARCH ON THE DEVELOPMENT OF RENEWABLE ENERGY}

Modern research in the field of renewable energy determines the directions of practical implementation of different energy sources. The possibility of rapid practical application of such results is crucial for economic growth. In the paper analyses the advanced publications as the results of fundamental researches for different directions of renewable energy and identifies the key points that have influenced the practical development of each of these areas. It is shown how scientific research in different countries after the practical implementation affects their economic development. The key players in the global renewable energy market have been determined.

Keywords: Renewable energy, publications, scientific research, $h$-index. 